THE ARTIFICIAL INTELLIGENCE MODEL OUTPUT ANALYZER

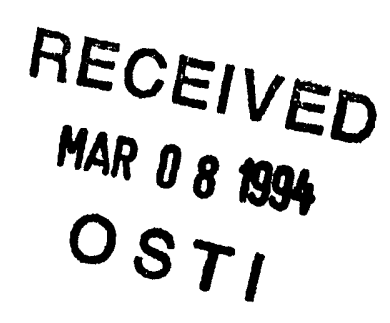

K. D. Strauss ${ }^{(a)}$

January 1994

Presented at the

10th International Conference on Interactive

Information \& Processing Systems for Meteorology, Oceanography \& Hydrology

January 23-28, 1994

Nashville, Tennessee

Work supported by

the U.S. Department of Energy

under Contract DE-ACO6-76RLO 1830

Pacific Northwest Laboratory

Richland, Washington 99352
(a) Pacific Northwest Laboratory
Sequim, Washington
DISCLAIMER

\begin{abstract}
This report was prepared as an account of work sponsored by an agency of the United States Government. Neither the United States Government nor any agency thereof, nor any of their employees, makes any warranty, express or implied, or assumes any legal liability or responsibility for the accuracy, completeness, or usefulness of any information, apparatus, product, or process disclosed, or represents that its use would not infringe privately owned rights. Reference herein to any specific commercial product, process, or service by trade name, trademark, manufacturer, or otherwise does not necessarily constitute or imply its endorsement, recommendation, or favoring by the United States Government or any agency thereof. The views and opinions of authors expressed herein do not necessarily state or reflect those of the United States Government or any agency thereof.
\end{abstract}




\title{
THE ARTIFICIAL INTELLIOENCE MODEL OUTPUT ANALYZER
}

\author{
Kimberly D. Strauss \\ Pacific Narthwest Laboratary \\ Sequim, Washington
}

\section{INIRODUCIION}

The Ocens Lerge Eddy Model (OLEM) (Denbo and Skyllingated, 1992) is us coenographic. noa-bydroitatic, Large-eddy almulation model designed to resolve mill-acele, tonbulent, non-bydrosutic processes. It has recently been used in the soudy of thermobaric convection and the aseocinted convective phumes. These plumes are crested whan small, vertical perturbettoms in the bottom of the shallow mixed layer become unsteble due to the thermobaric instability. This instability occurs beceuve water has different compressibility at different temperatures and salinities. Convective plumes are an important component of the globel meridional cocas cireulation, affecting oceanic tranopartation and sborage of heat and carbon dioxide, which in tarn affect the global climete.

Reserrch on plumes is important for better under. stending of the effect of this deep. penotrative convection on meridionel cinculation. General statistica tbout plumes will be used to assess the qualiny of the representution of processes in large cocem models. However, weh statistics on plumes are difficult to calculate. due primurily to difficulty in determining exectly what is or is not a plume. This difficulty led to the creation of the "artificial intelligence model curput analyzer."

Plumes are primarily identified as areas of water with high downward veloctity $(w)$ surounded by ureas with moderaie upward velocity (Figure 1). These seas weo bave relatively low temperature (t), and relatively high mubgrid turbsilent binetic energy (tke) values. All three of these factors as well as the proxtmity to outer weas with similer and different characteristics must be treen inw eccount to identify a phrme. With the large movers of date being analyzed, menual identification becomes uarealistic.

Corresponding author address: Kimberly D. Strawss, Padfic Northwast Laboratory, Battelle/Mrrine Sciences Laboratary, 1529 W. Sequim Bay Roed. Seguim Wash.

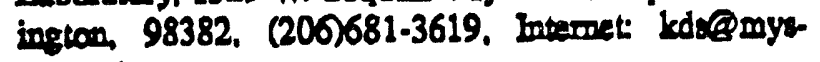
tery.pol.gov.

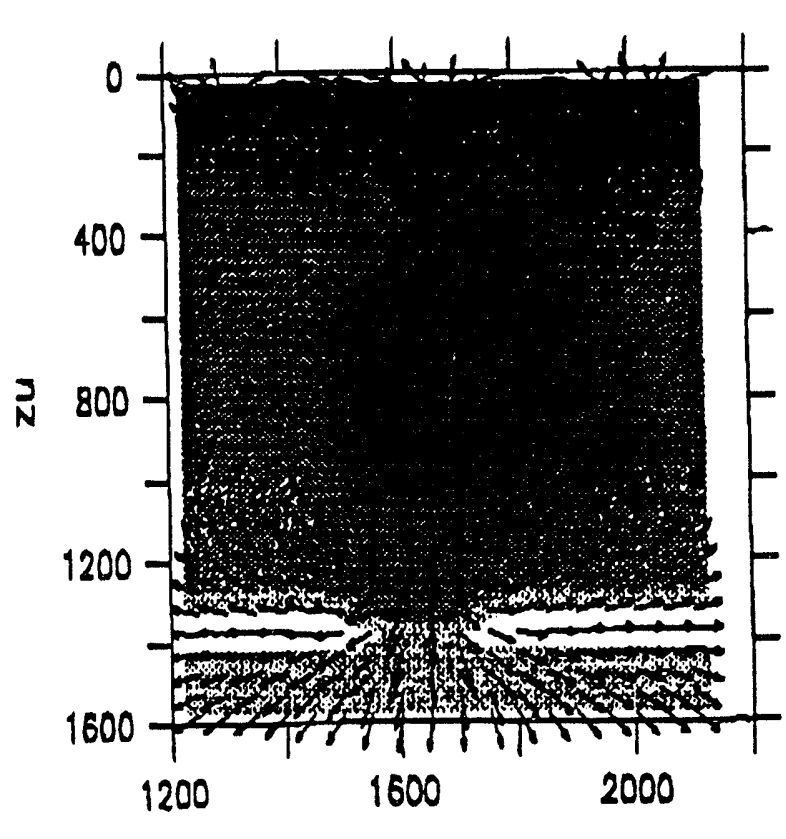

Figure 1. The temperature and vertical velocity of water in and uround a plume. Tho derber colors indicate cooler remperatures. The velocity vectors indicate anly directorn, not magnitude.

\section{THE MODEL OUTPUT ANALYZZER}

The model output malyzer takes as inpus a neCCDF (Row and Davis, 1990) file in the format of OLEM output files. The files, contrining a timo bistory of the three-dimensional velocity, the and temperature fields. is well as the data for weveral ocher variables, ofter exceed 1.5 gigabytes in tire.

\subsection{The Cenfidence Arrow}

There are several steps involved in identifying plumes in these duta. The first is to go through the model output array and determine a value that expreses the program's confidence that each point is in a plume. The progem looks at the relevent fields and modifies the confidenco value according to the values in there felds. 


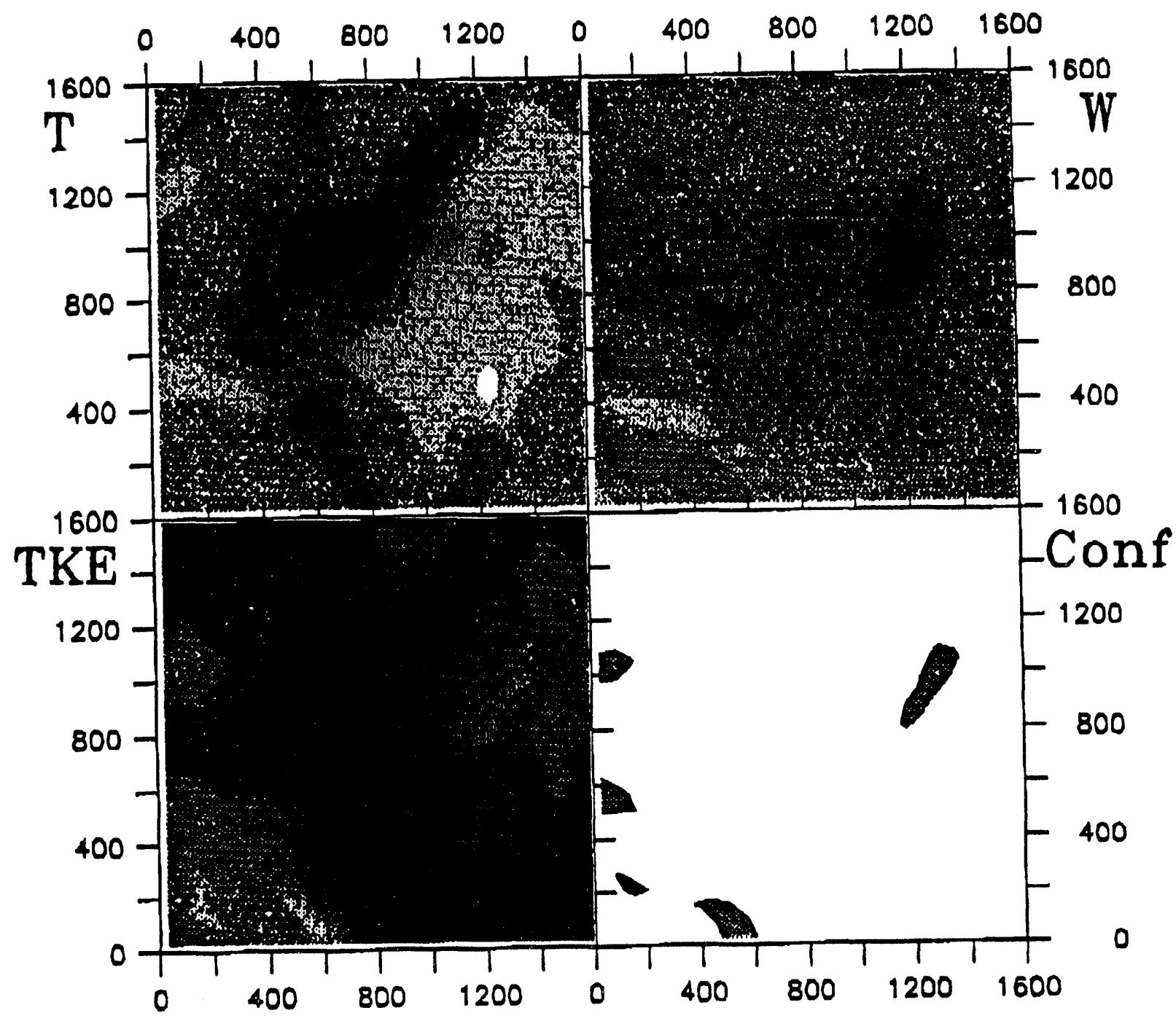

Figure 2. The temperature, vertical valocity and the fields compared to the confidence array. The derk areas indicate low temperature. bigh dowawerd velocity and low tike. The shaded areas in the confidence aray indicate ureas with confidence of $25 \%$ or more.

The program first looks at the vertical velocity, the most importent element of a plume. The program goes through the velocity exray at a given time-step and finds the averige vertical velocity and the bighest downwand velocity. It then goes through the arrey, assigoing a value to exch point rocording to it's velocity in relationhip to these vahues. Any point whose veloctly is upwerd gets a confidence valus of 0 . Points with : downwand velocity higher then the average get a confdence value dependant on the differenco fram the averase and a user-specified weighting factor. This factor determinas the percentage of confidence influenced by esch of the impartmot elements ( $t, w$, the, and neighboring points).

The process is repeated for the temperalure and the of eseh of the poinss, except those points with a confi. dence value of 0 . These poins leep thetr 0 confidences, since points cennot be in 1 plume without dowawerd vertical velocity.

The last test looks at the naighboring points. Esech comfidence value greater then 0 is incresued by the con. fidence of the points around it, adjusted by a user specifled weighting factor. This strengthens the confidence of groups of points, emphesizing plumes over anomalies. 
The confidence array gives consistent results compared to mamial methods. Although it gives confidence values graiter then 0 for plumer, surfice waves, and internal waves, when st 3 user looks only at confidences above $25 \%$, tho results identify only plumes and the remainders of plumes.

Figure 2 illuatraties a inmple of the confidence array. There is a bigh correlation between the high dowaward velocity and the confidance masy when at least ane of the other fields also hes the carrect charecteristics. However. figure 2 also demonstrates how the confidence aray distinguishos between plumes and mamalies. Areas with only one of the fields as in indicator (i.e. the region of low temperature in figure 2) does not show up is a plume in the confidence array.

\subsection{Plumeldentification}

The rext stop is identifying which points bend together to make up $\&$ plume. The user first inpuss the conflance lovel required to be considered part of a plume. Each point with a high enough confidence level is considered. The progrem loaks at the poirt to the left of each point If it is in a phume, the new point is added to that plume. If not, the program looks at the previous now to see whether the point next to it in that row is part of a plume. If so. the now point is added to that plume. If both of the tests are true, it checks to make sure that all three poins are in the sume plume. If neifher test is true, a new plume is searted.

Once a dapth level has been classified into plumes versus noo-plumes. It is compered with the next depth lower to combing the phumes that exist in both layors. A phume with two or mare plumes below it is considered a merged plume. A separate account of merged plumes is bept in order to use these statisties once their dynamic signifences is understood. The progran does not attempt to follow phumes betwean tho-steps, due to the significant movement of the plumas during the period between time steps.

\subsection{Eind Plome Centers}

The next step involved in identifying plumes for ocaristics is to identify the "center" of a plumo. This cen. ter consists of a line going through the middle of the phime with a single point at every depth. There are meny ways this center can bo calculated, and rix methods are evailable for the user to ty. These methods are the following: 1) the highest confidence at each depth, 2) the physical center of the phume. 3) a weighted physical center which includes confidences as well as locer. tions in the calculation, 4) the highest downward velocity, 5) the highest wemperature, and 6) the highest thes.

\subsection{Statistics}

Oxce the plumes and centars are Identified, it is possible to calculate many atetistica. Currently, the ststistice tretuded are the average mumber of plumes at a given time and the coul water vatume in phomes. in merged phumes, and in seither. Thase volumes can be calculated by time. depth, average $\alpha$ overall. Many more statistics are planned, including the average gize of plume, the average velocity and other statibtice as points certain distances from the center of a plume, the averape bottom depth and meny others. This program is designed to be used is a coolldit of furctions the users cen call from their own programs and ase interactively.

\section{CONCIUSTON}

With the ereation of the artificial intelligence model output inalyzes, the evaluation of leros numbers of plumes in large data sets has become realistic. If allows the user to adfust freton and confidence limits until there is coufidence that the phumes found by the ma. lyzer are to agrecment with the plumes formd mamully. These values cm then be used to compute otherwise difficult statistics on large numbers of dats sets and pluroes. These statistics will essist researchers in tmproving large seale cocan models.

\section{ACLNOWLEDGEMRNTS}

This research was supported by the U.S. Department of Energy (DOE) under Contract DE-ACO67GRIO 1830. Battelle/Merine Sciences Laboratary is part of the Pacific Northwest Luborabory, operated for DOE by Battelle Memorial Instinute.

\section{REFERENCES}

Denbo, D.W., and E.D. Skyllingstad, 1992. "Rotstional Effects an Ocesnic Convection using a ThreoDimensionel Nonbydrostatic Modal." EOS, Trans. Amer, Geophys. Union, 73:292.

Rew, R.R., and G.P. Devis. 1990. "The Unidres netCDF: Software for reientific data eccoss." Sixth Interiational Conference on Interactive Information and Processing Syetems for Meteorology, Ocenaography and Hydrology. Feb 5-9, 1990, Anabeim, CA. 

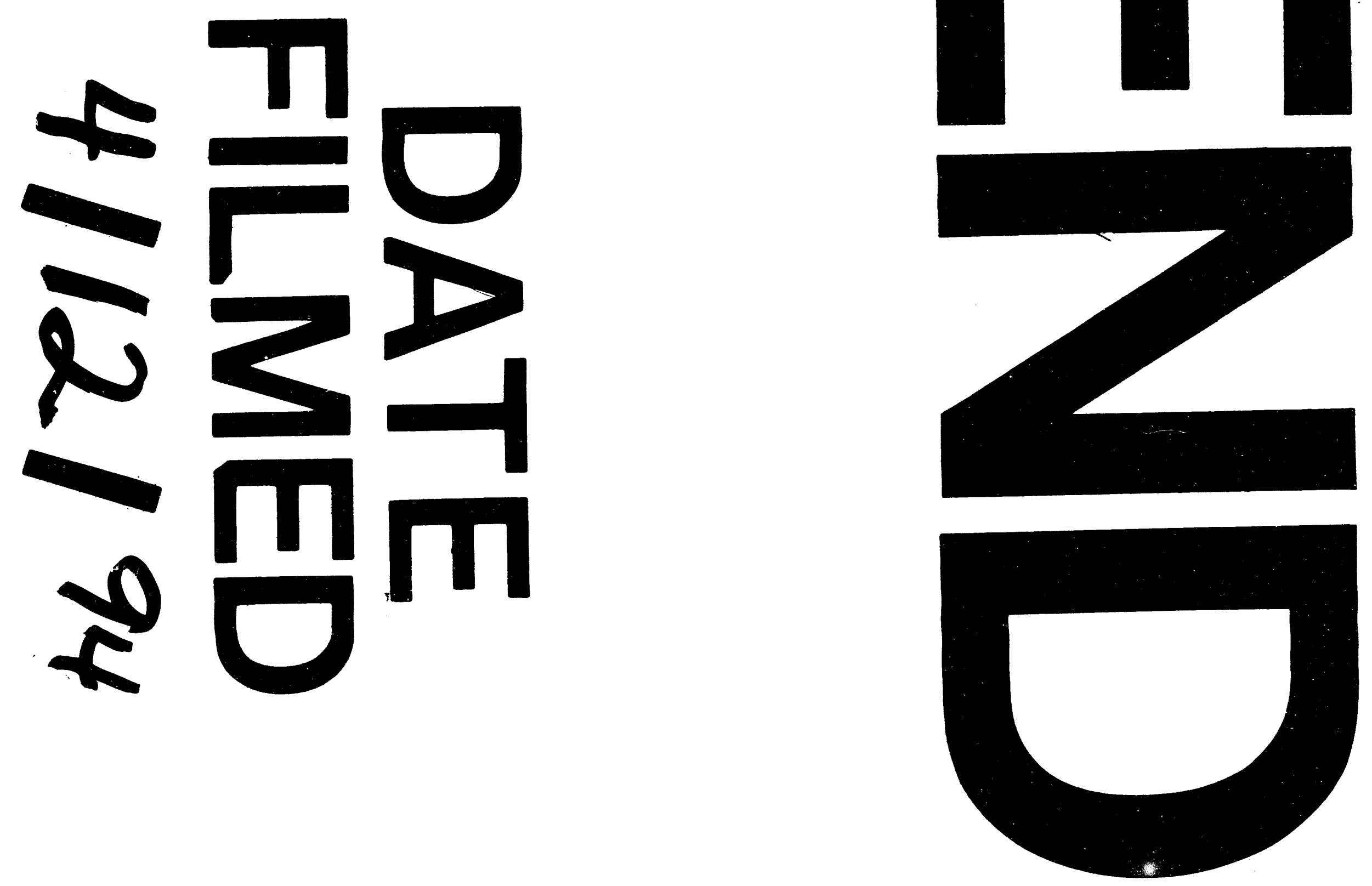

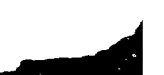


